Mode-locked fiber laser for ultrashort optical pulse generation and telabit optical transmission

高良 秀彦（N T T 光ネットワークシステム研究所）

Hidehiko Takara (NTT Optical Network Systems Laboratories)

\title{
1.はじめに
}

現在、来るべきマルチメディア時代に対応しうる次世代光ネットワークの構築を目指して、テラビット級の光伝送方 式の研究が進められている[1][2]。電子回路を用いた信号処理による時間分割多重方式ではビットレートは数10 Gbit/s程 度が限界であり、テラヒッット級光伝送方式を実現するには光処理による多重が必須である。この光多重には、光時分割 多重 (OTDM) 技術と、波長多重（WDM）技術がある。图１に光処理技術による超高速・広帯域光伝送実験の進展を示 す。このような光多重伝送方式の実現には、送信系の光源に対して従来より高度な特性が要求される。OTDM技術にお いて多重数を增大するためには短パルス化、低ジッタ化が必須であり、伝送路の分散の影響を最小限とするためにトラ ンスフォームリミット(TL)な光パルスを発生する技術が必要とされる。一方、WDM技術で多重数を增加するには波長の 異なる光信号が必要となる。従来のWDM伝送では多重と等しい数の光源を使用しているが、単体で多波長の光信号を安 定に発生する光源を開発することで、より信頼性、経済性に優れた送信系の実現が期待できる。我々は、これまで

OTDMとWDMを融合した大容量光伝送用光源への適用を目指して、モード同期E添加ファイバレーザおよびスーパーコ ンティニアム（Supercontinuum； SC）による超短・広带域光パルス発生について検討を進めてきた。本稿では、本技術 およびテラビット光伝送および光計測への応用について紹介する。

\section{2 モード同期Er添加ファイバレーザ}

超高速OTDM伝送に適用するために信号光源は、(1) 短光パルス、(2) 低ジッ夕、(3) TL、(4) 繰り返し周波数数 $\mathrm{GHz}$ $20 \mathrm{GHz}$ )、(5) 外部との同期の各条件を涌足する必要がある。(1)(2)は多重数を上げて高ビットレート化を図る上で重要で

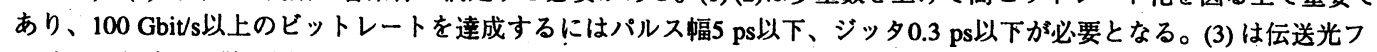
アイバにおける分散の影繁を最小とするために必要である。(4)(5)は1チャンネルのビットレートを電気処理が可能な速 度とし、電気段と光段との同期をとるための条件である。

超高速光伝送用として有望な光源の一つに能動モード同期Er添加ファイバ(ML-EDF)レーザがある（図 2 ）。このMLEDFレーザの特性を表 1 に示す。6 20 GHzでsech型のTLに近いパルス幅3〜5 ps、ジッタ0.1 ps以下の光バルス発生が可能 であり、上記の条件を满足する優れた特性を持つ。ただし、長共振器構造（10 m以上）のため振動や温度変動に起因す る偏波や共振器長の変化により動作が不安定になりやすいという問題点がある。我々は共振器を偏波保持構成とするこ とで偏波変動の除去に成功した。さらに不安定動作時の緩和振動周波数成分の発生に着目し、これをフィードバック信

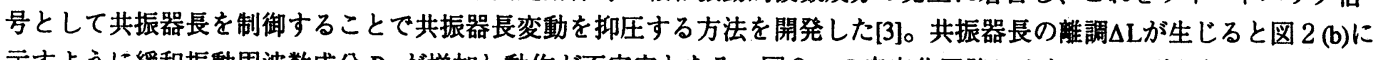
示すように緩和振動周波数成分 Pr が增加し動作が不安定となる。図 2 (a)の安定化回路により、レーザ出力の一部を分岐 して受光器で Pr 成分のみを検出し、コンピュータにより Prを最小とするように光遅延器を制御することで共振器長の 安定化を行うことができる。この安定化法により、10時間以上のパルス久落のない安定な動作を実現している。本方法 は、安定性の指標となる楥和振動成分を直接観測するため信頼性の高い動作安定化が実現できる。これまで信号光源と して本安定化ML-EDFレーザを用いることで、100 Gbit/s, $560 \mathrm{~km}$ (中継間隔80 km) のOTDM伝送に成功している[4]。

\section{3. スーパーコンティニアム}

上記ML-EDFレーザ出力をSC光に変換することで、さらに高速のOTDM光伝送が可能となる。SC光とは高強度の光パ ルスが非線形光学媒質を通過することで発生する広带域のスペクトルを持った光パルスである(図 3)[5]。上記ML-EDFレ ーザからの 3 ps光パルスをEDFAによりピークパワー1〜2Wに增幅した後、SC発生用の低分散光ファイバに入射する。 光パルスは、SCファイバ内で自己位相变調および四光波混合等の非線形光学現象の複合効果により200 nm以上の広バン ド幅を有するSC光に変換される。表 1 にSC光の特性を示す。このSC光から光フイル夕により波長成分を切り取ること

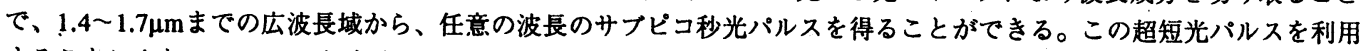
することにより、400 Gbit/s超高速OTDM妘送を実現した[6]。また後述のように光サンプリング波形測定技術のゲートパ ルスとしても適用することができる。

\section{4. 光サンプリング}

超高速光伝送を実現するためには、システム全体や構成要素の特性をサブピコ秒の時間領域で評価する必要がある。 


\section{レーザー学会学術講演会第17回年次大会}

我々は、2 次の非線形光学効果である和周波数光発生（SFG）および上記のSC光を利用した光サンブリング法による高 速光信号の波形測定について検討を行ってきた(図4)[7]。繰り返し周波数 $f_{0}$ の信号光（光周波数 $v_{s i g}$ ）と、繰り返し周波 数 $f_{0} / n-\Delta f$ のサンプリング光パルス（光周波数 $v_{s a m}$ ）の 2 種類の光を非線形光学結晶に入射すると、 2 光の相互相関 信号である和周波光 $\left(v_{\mathrm{sfg}}=v_{\mathrm{sig}}+v_{\mathrm{sam}}\right)$ が発生する。サンプリンク光パルスは信号光との相対位置をずらしながら掃 引するため、和周波光出力の包絡線は信号光波形の時間軸を拡大した波形である。この和周波光出力を受光系で検出す ることにより超高速光波形観測が可能となる。本方法の時間分解能は光波形を切り取るサンプリンク光パルス幅に依存 する。このサンプリング光パルスとして $0.3 \mathrm{ps}$ のSC光を用いることにより、0.5 psの高時間分解能を達成している。

また、ランタムに変調された短光パルス信号のアイパタン測定は、マーク、スペース時の光強度分布およ びジッタ等の光伝送特性の評価に重要である。サンプリング光の高出力化と、高光非線形性を有する有機結 晶AANP（2-adamantylamino-5-nitropyridine）の使用による測定系の高感度化を図り、高速光信号のアイパ タン測定を実現した[8]。図 4 (b)に各種測定法による $100 \mathrm{Gbit} / \mathrm{s}$ 光信号の測定波形を示す。従来技術である高 速受光器やストリークカメラを用いた方法では低時間分解能や平均化処理が原因でアイパタン測定は不可能 であったが、光サンプリング法を用いることにより、初めて $100 \mathrm{Gbit} / \mathrm{s}$ 光信号のアイパタン測定に成功した。

\section{5. テラビット光伝送}

またSC光は短バルス性とともに広帯域性も有するため、SC光から同時に多波長成分を抽出して独立に変調することで 波長多重用光源としても利用できる。このSC光の短パルス性と広带域性の特性を活かして、1 Tbit/s $(100 \mathrm{Gbit} / \mathrm{s} \mathrm{x} 10 \mathrm{ch})$ 光伝送実験を行った[1]。実験系を図 5 (a)に示す。送信側では単一のSC光源からの広帯域光パルスを光強度変調器で変調 し、10 Gbit/s信号光を光時分割多重回路で10多重して100 Gbit/s信号光とし（図 5 (b)）、さらにアレイ導波路格子型光分 波器（AWG）によって10種類の波長のパルス列を切出し波長多重した（図 5 (c)）。つぎに、多重化された100Gbit/s $\times 10$ 波長の1 Tbit/s信号光は広帯域のエルビウム添加フッ化物光ファイバ増幅器で一括増幅し、全長40 kmの光ファイバ伝送 路を伝送した。受信部では、まず光分波器によって1 Tbit/s信号を波長領域で10チャンネルの100 Gbit/s信号に分離した。 次に各波長の $100 \mathrm{Gbit} / \mathrm{s}$ 信号は 2 分岐され、一部をブリスケールPLLタイミング抽出回路に、残りを全光時分割分離回路 に導いた。プリスケールPLLタイミング抽出回路では、半導体レーザの4光波混合光発生(FWM)を利用して、光ファイバ 通過後の $100 \mathrm{Gbit} / \mathrm{s}$ 光信号の時間摇らぎに追随した10分の 1 の基本周波数信号 $(10 \mathrm{GHz})$ ．を直接抽出した。全光時分割分 離回路でも、FWMを利用して、タイミング抽出によって得られたクロックに従い時分割多重された100 Gbit/s光信号から $10 \mathrm{Gbit} / \mathrm{s}$ の光信号10系統への分離を行った。以上の伝送系で、1 Tbit/sの光多重信号が40 kmの光ファイバ内をビット誤り なく伝送し、本光源のOTDMおよびWDM用光源としての有効性が実証できた。

SC光は、サブピコ秒光パルス発生が可能なためOTDMでの多重度をさらに上げることができる。WDMの多重度を規定 する200nm以上の波長範囲と併せて、その潜在的伝送容量は5Tbit/sを超えるものと考えられる。

\section{6. おわりに}

以上述べたように、モード同期Er添加ファイバレーザおよびスーパーコンティニアム技術によって、光時分割多重、 波長多重に適した超短、広带域光パルスが得られ、将来のテラビット級光ネットワークの実現に大きく近づくことがで きる。また、光サンブリングのような高度な光計測も可能となり、今度の発展が期待される。

\section{参考文献}

[1] T.Morioka et al.,"100Gbit/s $\times 10$ channel OTDM/WDM Transmission using a Single Supercontinuum WDM Source", Tech.Digest of OFC'96, PD21, 1996.2.

[2] Y. Ono et al., "2.6 Terabit WDM tranmission experiment using optical duobinary coding", ECOC'96, Tub.3.1, 1996.9. [3] H. Takara et al. ,"Stabilising mode-locked Er-doped fibre laser by suppressing relaxation oscillation frequency component," Electron. Lett., 31, pp. 292-293, 1995.

[4] S.Kawanishi et al.,"100 Gbit/s, $560 \mathrm{~km}$ optical transmission experiment with $80 \mathrm{~km}$ amplifier spacing employing dispersion management," Electron.Lett., Vol.32, No.10, pp.470-471, 1996.

[5] K. Mori et al., "Continuously tunable optical pulse generation utilizing supercontinuum in an optical fiber pumped by by an amplified gain-switched LD pulses", OAA'93, MD11, 1993.

[6] S.Kawanishi et al.,"Single channel $400 \mathrm{Gbit} / \mathrm{s}$ time-division-multiplexed transmission of 0.98 ps pulses over $40 \mathrm{~km}$ umploying dispersion slope compensation," Electron.Lett., Vol.32, No.10, pp.916-918, 1996.

[7]高良 他,「和周波光発生を用いた光サンブリングによる超高速光波形測定法」，電子情報通信学会論文誌B-1, vol. J75B-1, pp.372-380, 1992.

[8] H. Takara et al., "Eye-diagram measurement of $100 \mathrm{Gbit} / \mathrm{s}$ optical signal using optical sampling", ECOC'96, B.1.2, 1996.9. 


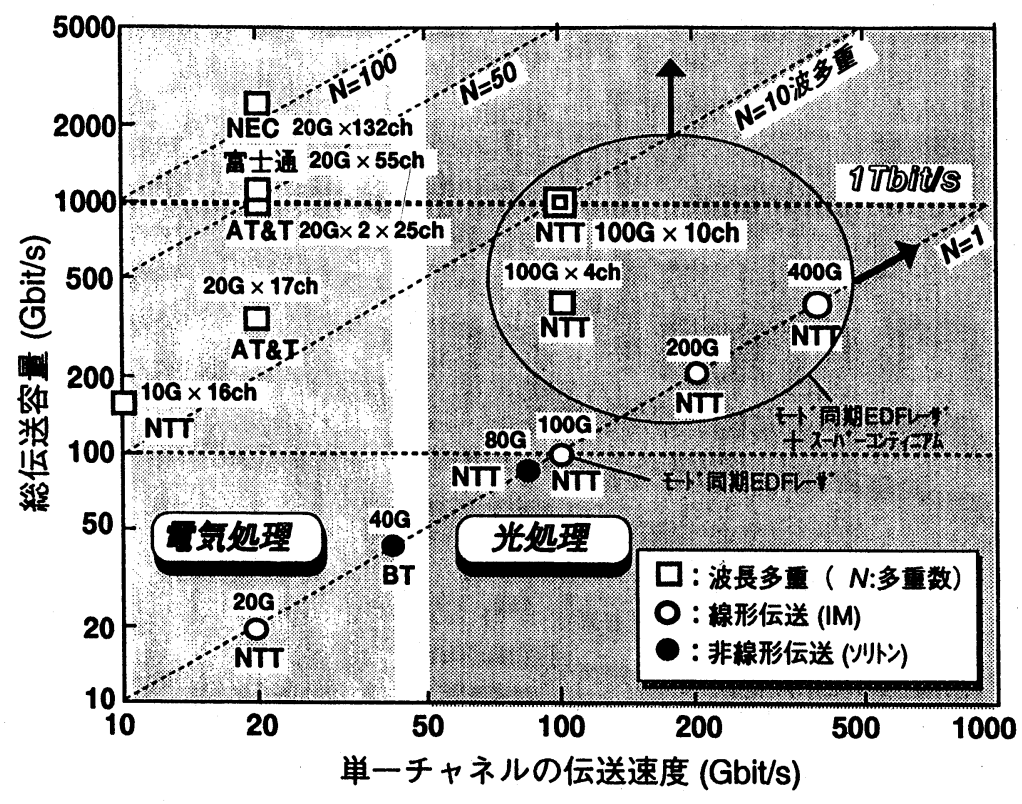

国1.大容青光伝送技術の進展

表 1.モード同期Er添加ファイバレーザおよびスーパーコンティニアムの特性

\begin{tabular}{|c|c|c|c|c|c|}
\hline 方法 & パルス蛆 & ジッタ & 时间ハントド稍 & 波县可麦性 & 细り返し周波数 \\
\hline 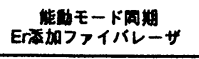 & $3 \sim 5$ ps & $<0.1 \mathrm{ps}$ & 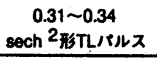 & $\sim 30 \mathrm{~nm}$ & 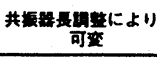 \\
\hline スーパーコンティニアム & $<1$ ps & $<0.1$ ps & 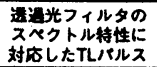 & $>200 \mathrm{~nm}$ & 㽖起光洒と用し \\
\hline
\end{tabular}

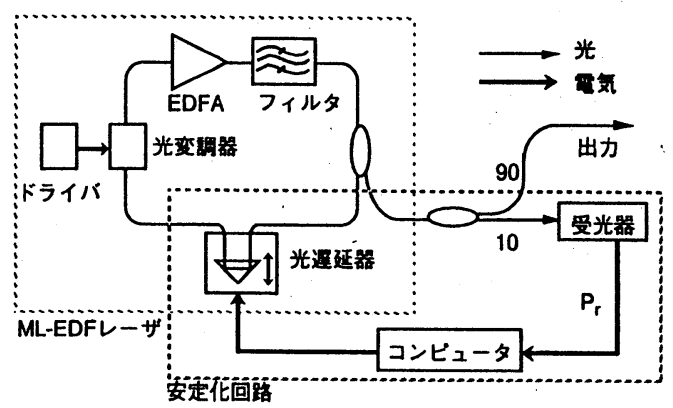

(a) 構成㘣

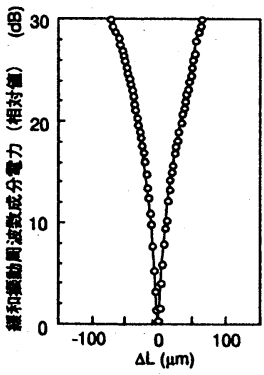

(b) 共振器長離調特性

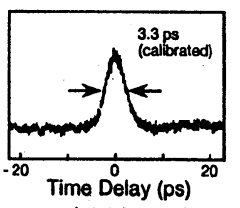

(c) 自己相関波形

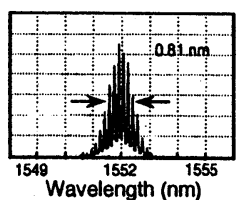

(d) スペクトル

図2、能動モード同期Er添加ファイパレーザ 


\section{レーザー学会学術講演会第17回年次大会}
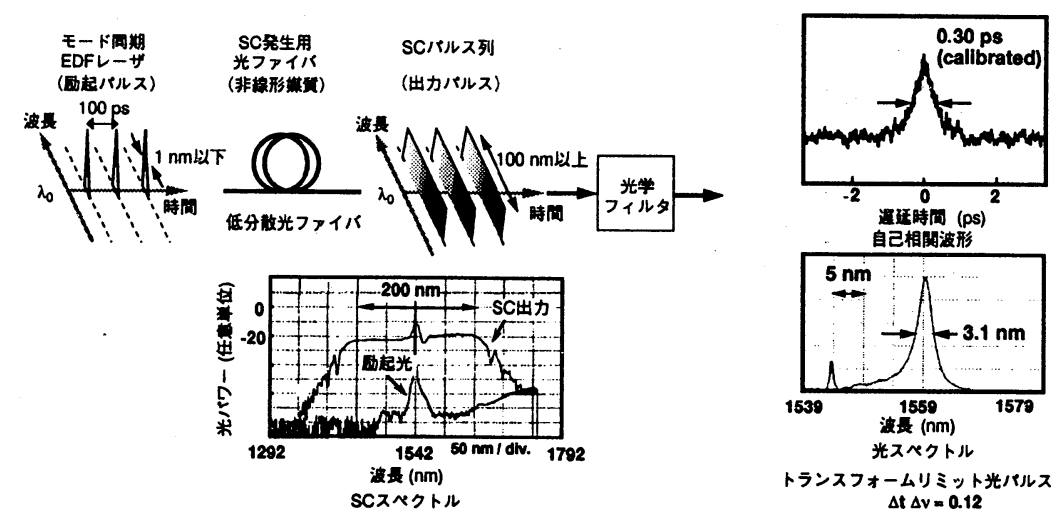

図3.スーパーコンティニアム光発生

トランスフォームリミット光パルス $\Delta t \Delta v=0.12$
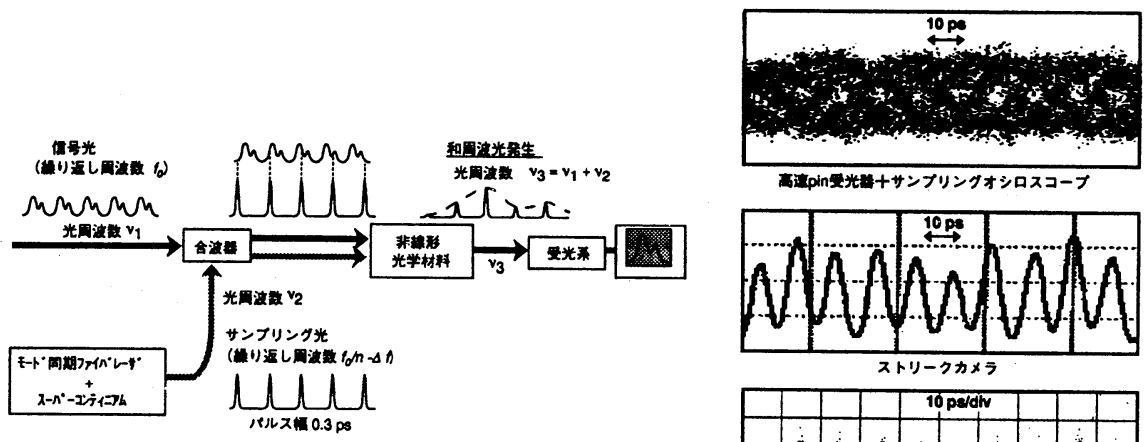

(a) 矅定系
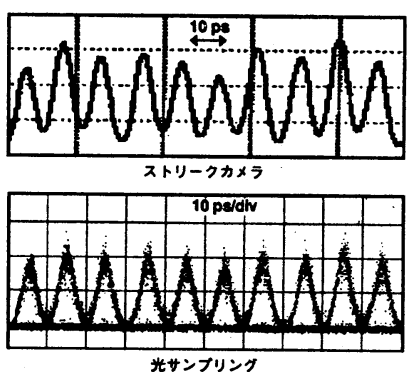

(b) $100 \mathrm{Gbit} / \mathrm{s}$ 光位号波形

图 4．光サンブリング光信号波形測定

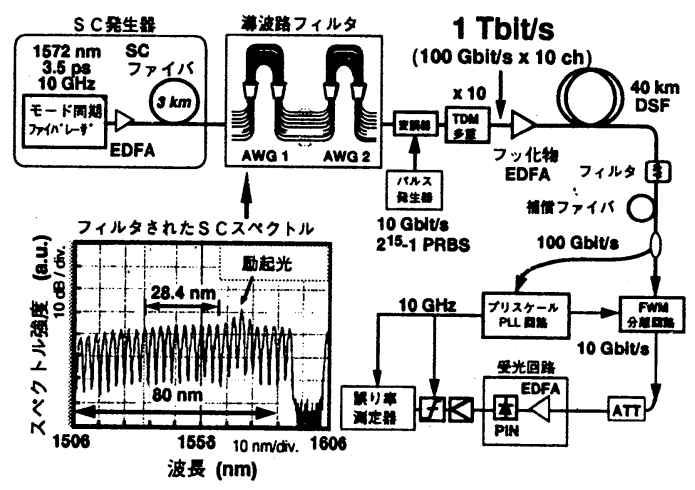

(a) 実険系

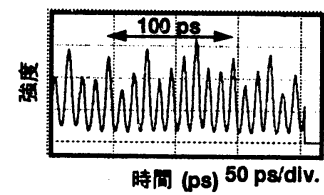

(b) 伝送位号の時䦗波形 $(100 \mathrm{~Gb} / \mathrm{s})$

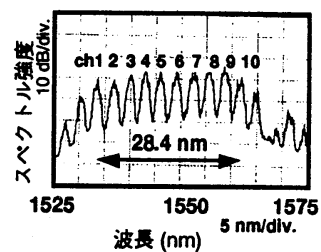

(c) 伝送信号のスベクトル $(100 \mathrm{~Gb} / \mathrm{s} \times 10 \mathrm{ch}=1 \mathrm{~Tb} / \mathrm{s})$

図 5.1 Tbit/s光伝送 